\title{
DAYA SAING PALA, LAWANG, DAN KAPULAGA INDONESIA DI PASAR
} INTERNASIONAL

\section{COMPETITIVENESS OF INDONESIAN NUTMEG, MACE, AND CARDAMOM IN THE INTERNATIONAL MARKET}

\author{
Nyimas Aliya Suhartini*, Riantin Hikmah Widi, Dedi Darusman \\ Jurusan Agribisnis, Fakultas Pertanian, Universitas Siliwangi \\ *E-mail corresponding: aliyashrtn168@gmail.com
}

\begin{abstract}
ABSTRAK
Penelitian ini bertujuan untuk menganalisis daya saing pala, lawang, dan kapulaga Indonesia di pasar internasional dilihat dari posisi atau kecenderungan Indonesia sebagai importir atau eksportir, keunggulan komparatif Indonesia, dan spesialisasi ekspor Indonesia untuk komoditas pala, lawang, dan kapulaga (rempah HS 0908). Metode yang digunakan adalah studi kasus. Data yang digunakan adalah data sekunder runtun waktu (time series) periode tahun 2004-2018. Penelitian ini dilaksanakan dari bulan Januari 2021 sampai dengan Agustus 2021. Analisis menggunakan Indeks Spesialisasi Perdagangan (ISP) untuk menganalisis posisi atau kecenderungan negara Indonesia sebagai eksportir atau importir pada komoditas pala, lawang, dan kapulaga, Revealed Comparative Advantage (RCA) untuk menganalisis keunggulan komparatif pala, lawang, dan kapulaga Indonesia, dan Comparative Export Performence (CEP) untuk menganalisis spesialisasi ekspor rempah HS 0908 Indonesia ke pasar internasional. Hasil penelitian menunjukkan bahwa rempah HS 0908 Indonesia memiliki daya saing di pasar internasional. Hal tersebut dilihat dari kecenderungan Indonesia sebagai eksportir rempah HS 0908 dengan rata-rata nilai ISP 0,983. Indonesia memiliki keunggulan komparatif dengan rata-rata nilai RCA 21,597. Ekspor pala, lawang, dan kapulaga Indonesia pun sudah terspesialisasi dengan rata-rata nilai CEP 3,028. Indonesia menjadi negara dengan daya saing tertinggi kedua setelah Guatemala yang memiliki rata-rata nilai ISP 0,997 , rata-rata nilai RCA 885,830 , dan ratarata nilai CEP 6,731. Posisi ketiga diduduki oleh India yang memiliki rata-rata nilai ISP 0,229 , rata-rata nilai RCA 8,404, dan rata-rata nilai CEP 2,099. Sedangkan posisi keempat diduduki oleh Netherland yang memiliki rata-rata nilai ISP $-0,026$, rata-rata nilai RCA 1,872 , dan rata-rata nilai CEP 0,583.
\end{abstract}

Kata Kunci : rempah HS 0908, daya saing, pasar internasional

\begin{abstract}
This research is intended to analyze the competitiveness of Indonesian nutmeg, mace, and cardamom in the international market judging by Indonesia's position as an importer or exporter, Indonesia's comparative advantages, and Indonesia's export specialization for nutmeg, mace, and cardamom commodities (Spice HS 0908). The method used is a case study. The data used is secondary data from the time series in the period 2004-2018. This research was conducted from January 2021 to August 2021. The analysis uses the Trade Specialization Index (ISP) to analyze the position or tendency of the Indonesian state as an exporter or importer of spice HS 0908, Revealed Comparative Advantage (RCA) to analyze the comparative advantages of Indonesian spice HS 0908, and Comparative Export Performence (CEP) to analyze the specialization of Indonesian spice HS 0908 exports to international markets. The results showed that Indonesian spice HS 0908 have competitiveness in the international market. This is seen from Indonesia's tendency as an exporter of spice HS 0908 with an average ISP value of 0.983. Indonesia has a comparative advantage with an average RCA value of 21,597. Indonesia's spice HS 0908 exports have also been specialized with an average CEP value of 3,028. Indonesia became the country
\end{abstract}


with the second highest competitiveness after Guatemala which has an average ISP value of 0.997 , an average $R C A$ value of 885,830 , and an average CEP value of 6,731 . The third position is occupied by India which has an average ISP value of 0.229 , an average RCA value of 8,404 , and an average CEP value of 2,099. While the fourth position is occupied by Netherland which has an average ISP value of -0.026 , an average $R C A$ value of 1,872 , and an average CEP value of 0.583 .

Keywords: spice HS 0908, competitiveness, international markets

\section{PENDAHULUAN}

Perdagangan internasional telah menjadi salah satu aspek penting dalam perekonomian negara di dunia termasuk bagi Negara Indonesia. Komponen inti dari perdagangan internasional ini tidak lain merupakan ekpor dan impor. Kebutuhan suatu negara yang tidak bisa selalu dipenuhi secara mandiri serta keunggulan negara lainnya dalam menghasilkan suatu produk secara berlebih menyebabkan perdagangan internasional tetap terjadi dan terus berkembang hingga saat ini.

Sekarang ini, perdagangan internasional tidak hanya digunakan suatu negara untuk memenuhi kekurangan domestik terhadap suatu produk dan mengekspor kelebihan dari produk yang dihasilkan domestik saja, melainkan menjadi salah satu aspek penting yang diperhitungkan untuk meningkatkan Produk Domestik Bruto (PDB) suatu negara. Perdagangan internasional terutama ekspor merupakan salah satu faktor yang menentukan peningkatan pertumbuhan ekonomi suatu negara termasuk Negara Indonesia.
Hal tersebut sesuai dengan teori Keynes (1936) di mana nilai PDB yang merupakan alat untuk menilai laju perekonomian suatu negara itu dipengaruhi oleh pengeluaran agregat yang terdiri dari pengeluaran konsumsi rumah tangga, investasi yang dilakukan oleh pihak swasta, pengeluaran pemerintah, dan ekspor neto.

Menurut Tambunan

(2004), Kegiatan ekspor impor juga berdampak nyata bagi perekonomian nasional Indonesia karena kegiatan ekspor impor dapat menyumbang pendapatan nasional negara atau produk domestik bruto (PDB). Menurut Hamdani (2012), Perdagangan internasional terutama ekspor merupakan faktor yang menentukan dalam meningkatkan pertumbuhan ekonomi sebuah negara, karena akan menciptakan peluang investasi, penyediaan lapangan kerja, optimalisasi penggunaan sumberdaya alam lokal, dan menambah devisa yang berguna untuk membiayai pembangunan sebuah negara.

Berkaitan dengan hal tersebut, Indonesia dapat mendorong kegiatan ekspor ke pasar internasional secara 
maksimal guna meningkatkan pendapatan nasional Negara Indonesia. Semakin tinggi kinerja ekspor Negara Indonesia, maka semakin besar pula dampak positif terhadap perekonomian Negara Indonesia.

Sekarang ini, keadaan perdagangan internasional Indonesia semakin ketat. Hal tersebut disebabkan oleh perkembangan era globalisasi yang menyebabkan setiap negara memiliki kesempatan untuk melakukan ekspor produk-produk yang dihasilkannya ke pasar internasional. Negara yang tidak memiliki kesiapan untuk menghadapi perkembangan yang terjadi di pasar internasional akan tersingkir oleh negara lainnya yang memiliki kemampuan untuk beradaptasi dengan baik dan dapat merespon perubahan yang terjadi dengan baik. Hal tersebut menyebabkan target pasar yang semula dikuasai oleh suatu negara dapat diambil alih oleh negara lainnya.

Persaingan antar negara produsen pun saat ini menjadi semakin ketat. Persaingan yang terjadi menyebabkan setiap negara produsen harus dapat meningkatkan keunggulan atau daya saing produk-produk yang dihasikan oleh negaranya agar produknya tetap diminati oleh negara importir. Semakin banyak pangsa pasar yang didapat maka semakin besar peluang keuntungan yang akan diperoleh oleh negara produsen dari hasil ekspor yang dilakukan. Hal tersebut pada akhirnya berdampak pada peningakatan ekonomi negara produsen.

Persaingan yang ketat menyebabkan negara Indonesia harus berjuang untuk tetap eksis dan bertahan di pasar internasional. Negara Indonesia memang memiliki sumber daya alam yang berlimpah. Banyak produk yang dapat dihasilkan oleh negara Indonesia untuk memenuhi kebutuhan domestik dan kebutuhan negara lainnya di pasar internasional. Namun hal tersebut tidak membuat Indonesia menjadi negara yang menguasai pasar internasional begitu saja.

Negara pesaing yang memiliki produk yang sama berusaha untuk dapat meningkatkan daya saing produk yang diekspornya. Negara pesaing berusaha untuk dapat menghasilkan produk yang sesuai dengan standar yang ditetapkan oleh negara importir dengan biaya produksi yang lebih efisien. Sejauh ini kinerja ekspor negara Indonesia pun masih mengalami fluktuasi setiap tahunnya.

Sebagai negara agraris, pertanian menjadi salah satu sektor yang memiliki peran cukup besar dalam menghasilkan pendapatan nasional bagi negara Indonesia. Banyak produk pertanian yang potensial untuk dikembangkan di pasar internasional, salah satunya rempah seperti pala, lawang, dan kapulaga. 
Ketiga komoditas tersebut tergabung internasional seperti UN Comtrade dan dalam kode HS 0908 pada data yang FAO.

disajikan oleh lembaga penyedia data

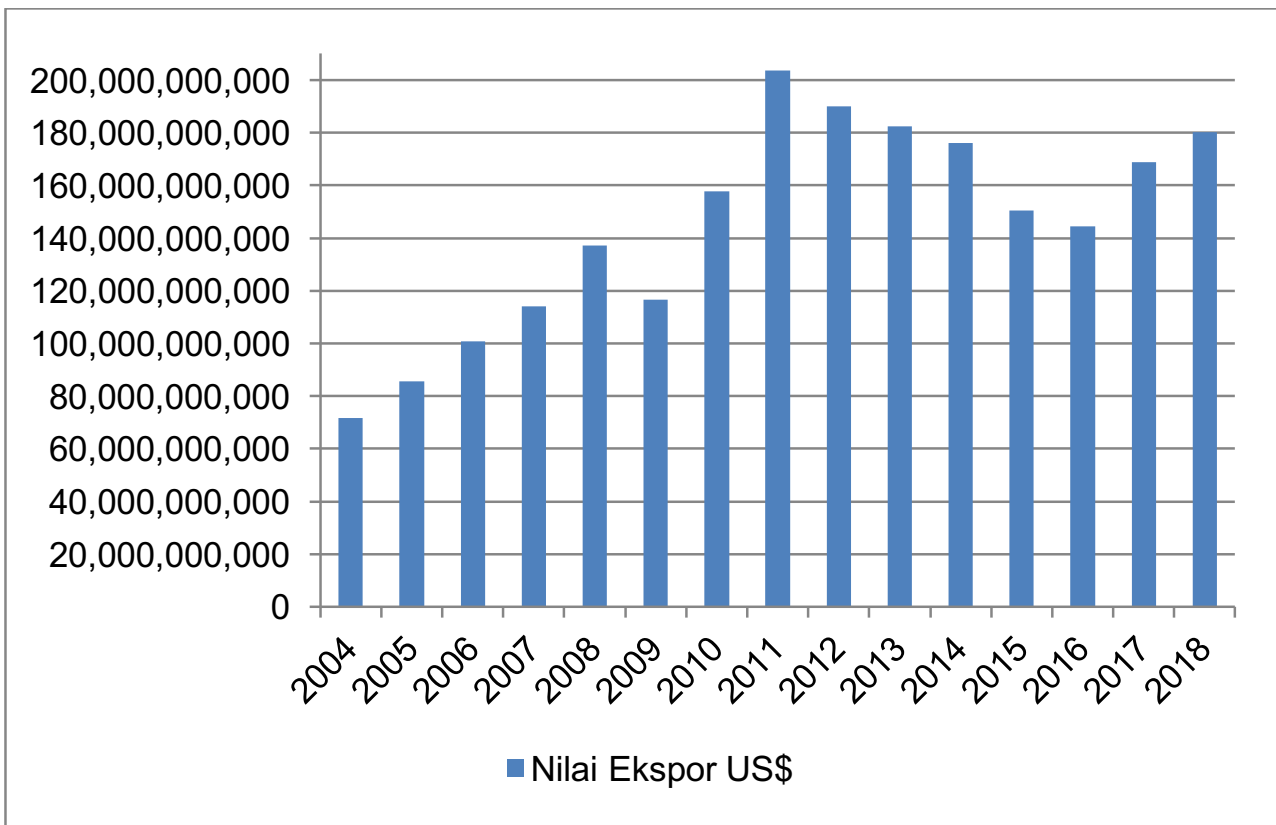

Gambar 1. Nilai Ekspor Negara Indonesia Tahun 2004-2018

Sumber: UN Comtrade (diolah), 2020

Permintaan komoditas pala, lawang dan kapulaga (yang selanjutnya disebut dengan rempah HS 0908) diprediksikan akan terus meningkat di pasar internasional. Hal tersebut distimulasi oleh (1) peningkatan konsumsi makanan khas berbahan tambahan pala, lawang, dan atau kapulaga (2) peningkatan produksi produk herbal seperti jamu, (3) penggunaan rempah sebagai bahan baku obat dalam bidang farmasi, (4) peningkatan kesadaran masyarakat terhadap kesehatan dan manfaat rempah, dan (5) penggunaan rempah sebagai bahan tambahan produk kosmetik. Sehingga tanaman pala, lawang, dan kapulaga sangat berpotensi untuk dikembangkan di Indonesia untuk kemudian diekspor ke pasar internasional.

Di Indonesia, rempah HS 0908 memiliki peranan yang cukup besar terhadap nilai ekspor rempah Indonesia ke pasar internasional. Tahun 2006 hingga tahun 2015 nilai ekspor rempah HS 0908 berkontribusi sebesar 12,15-32,38 persen dari total ekspor rempah Indonesia ke pasar internasional. Adapun rata-rata kontribusi ekspor rempah HS 0908 terhadap ekspor rempah Indonesia di pasar internasional adalah sebesar 22,15 persen. 


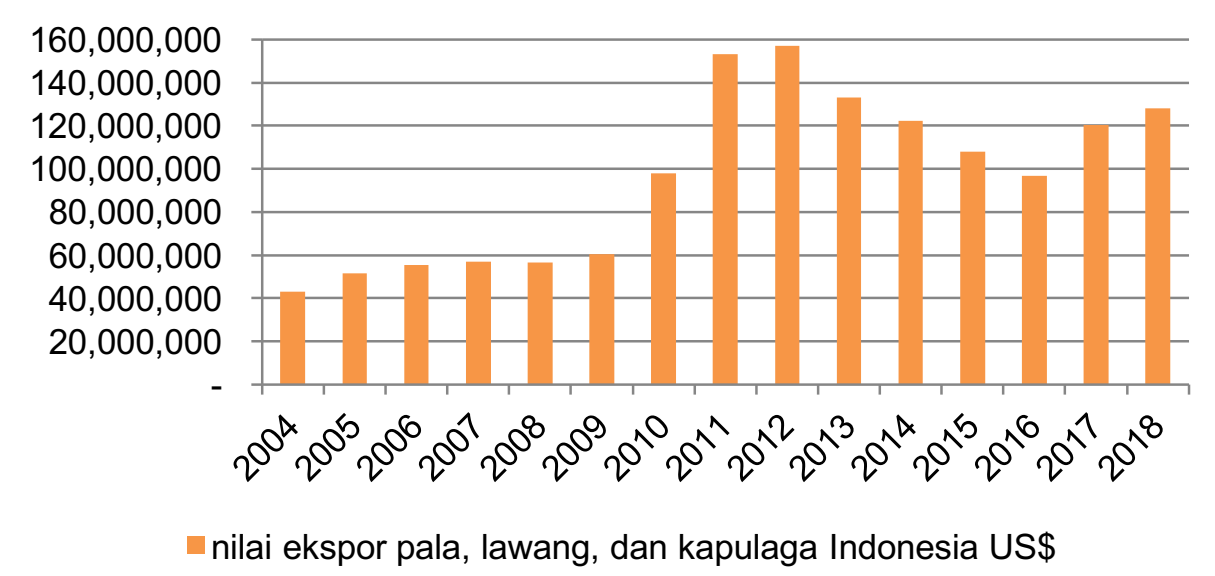

Gambar 2. Nilai Ekspor Rempah HS 0908 Indonesia di Pasar Internasional

Tahun 2004-2018

Sumber: UN-Comtrade, 2021

Berdasarkan Gambar 2, nilai ekspor rempah HS 0908 ini pada umumnya meningkat dari tahun 2004 ke tahun 2018. Tahun 2004, nilai ekspor rempah HS 0908 sebesar 42.827.008 US\$ dan pada tahun 2018 meningkat menjadi 128.181.495 US\$. Pada tahun 2013, terjadi penurunan nilai ekspor rempah HS 0908 menjadi 133.101.147 US\$. Penurunan tersebut terus terjadi hingga tahun 2016 menjadi sebesar 96.672.299 US\$. Penurunan ekspor rempah HS 0908 terjadi akibat produk rempah Indonesia yang kurang memenuhi standar kesehatan khususnya yang ditetapkan oleh Uni Eropa. Hal tersebut diperparah oleh perlambatan ekonomi pada tahun 2015 dan 2016 yang mempengaruhi permintaaan rempah HS 0908. Pemerintah Indonesia dan produsen rempah HS 0908 pun sudah berusaha untuk dapat meningkatkan kualitas produknya guna meningkatkan nilai ekspor rempah HS 0908. Nilai ekspor pun kembali meningkat di tahun 2017 dan 2018.

Meskipun demikian, nilai ekspor rempah HS 0908 Indonesia yang cukup tinggi dan kembali meningkat tersebut tidak memberikan jaminan bahwa daya saing rempah HS 0908 Indonesia lebih tinggi dibandingkan negara ekportir lainnya. Nilai ekspor yang dimiliki, belum tentu membuat Indonesia berada pada posisi sebagai eksportir pada komoditas tersebut. Maka, perlu dilakukan analisis untuk mengetahui kedudukan Indonesia dalam perdagangan rempah HS 0908 di pasar internasional.

Selain itu, keunggulan komparatif dan tingkat spesialisasi ekspor pada rempah HS 0908 pun perlu diketahui guna menilai sejauh mana daya saing 
yang dimiliki rempah HS 0908 Indonesia di pasar internasional, dibandingkan dengan daya saing negara lain pada komoditas yang sama di pasar internasional. Hasil penelitian ini dapat membantu pemerintah dan eksportir menganalisis daya saing rempah HS 0908 Indonesia di pasar internasional guna menentukan langkah pengembangan ekspor rempah HS 0908 di pasar internasional.

\section{METODE PENELITIAN}

Penelitian dilakukan mulai dari Januari 2021 hingga Agustus 2021 di Negara Indonesia dan negara pembanding yaitu Guatemala, India, dan Netherland. Lokasi penelitian ditentukan secara sengaja (purposive), dengan pertimbangan negara-negara tersebut merupakan empat negara eksportir terbesar pala, lawang, dan kapulaga (rempah HS 0908) di pasar internasional.

Penelitian ini merupakan penelitian yang menggunakan metode studi kasus.. Data yang dikumpulkan dalam penelitian ini terdiri dari data sekunder yang diperoleh dari UN-Comtrade, FAO, BPS, jurnal penelitian, dan lain sebagianya yang terkait dengan penelitian ini.

\section{Pendekatan Masalah}

Analisis yang digunakan adalah analisis deskriptif kuantitatif menggunakan Indeks Spesialisasi Perdagangan (ISP) untuk menganalisis posisi atau kedudukan Indonesia dalam kegaitan ekspor impor komoditas pala, lawang, dan kapulaga Indonesia di pasar internasional. Revealed Comparative Advantage (RCA) untuk keunggulan komparatif komoditas pala, lawang, dan kapulaga Indonesia di pasar internasional, dan Comparative Export Performance (CEP) untuk menganalisis tingkat spesialisasi ekspor pala, lawang, dan kapulaga Indonesia di pasar internasional.

\section{HASIL DAN PEMBAHASAN}

Gambaran Umum Pala Lawang, dan Kapulaga (Rempah HS 0908)

Tanaman pala dikenal sebagai tanaman rempah yang memiliki nilai ekonomis dan multiguna. Tanaman pala merupakan tanaman yang berasal dari Indonesia yaitu dari pulau Banda. Menurut Nanan Nurdjannah (2007), Daerah penghasil pala utama di Indonesia antara lain, Sulawesi Utara, Maluku, Nanggroe Aceh Darussalam, Papua, Sulawesi Selatan, Sumatera Barat dan Jawa Barat.

Indonesia merupakan salah satu negara pengekspor pala terbesar di dunia. Produksi pala di Indonesia relatif stabil dan cenderung meningkat sejak tahun 1994 yang berkisar antara 20 ribu ton per tahun (Nanan Nurdjannah, 2007). Berdasarkan data Ditjen Perkebunan (2018), produksi pala Indonesia tahun 
Vol. 3 No. 2 - November 2021

2018 mencapai 36.242 ton dengan luas areal tanaman pala $202.325 \mathrm{Ha}$. Total ekspor pala pada tahun 2018 tercatat sebanyak 20.202 ton.

Menurut Johan Utomo dan M. Verdi Suherman (2003), Tanaman pala tumbuh dengan baik di daerah-daerah yang mempunyai ketinggian 500-700 meter di atas permukaan laut. Pada ketinggian di atas 700 meter, produktivitas tanaman pala akan rendah. Tanaman ini membutuhkan tanah gembur memiliki pH 5,5-6,5. Jenis tanah yang cocok bagi tanaman ini adalah tanah vulkanis dan tanah yang bertekstur pasir sampai lempung dengan kandungan bahan organik yang tinggi, sedangkan temperatur yang cocok adalah sekitar 20-30 derajat celcius serta curah hujan terbagi secara teratur sepanjang tahun.

Tanaman Lawang merupakan tanaman yang berasal dari Cina. Tanaman ini mulai diperkenalkan di Eropa pada awal abad ke-17. Sejak saat itu, tanaman lawang mulai menyebar ke berbagai wilayah khususnya di wilayah Asia. Tanaman lawang dikenal dengan nama yang berbeda-beda. Orang keturunan Tionghoa di Jawa memanggil tanaman lawang sebagai pekak, sedangkan orang di Negara Eropa menyebutnya dengan Star Anise. Di Italia, tanaman ini dikenal dengan nama
Anice Stellato, dan masyarakat Jerman menyebutnya Sternanis.

Tanaman ini merupakan jenis pohon-pohonan atau perdu, dengan tinggi mencapai 4-6 meter. Memiliki daun tunggal, berbintik dengan ujung runcing. Bunganya berwarna kuning kehijauhijauan. Buah terdiri atas 6-8 folikel, masing-masing folikel berisi 1 biji (Tjitrosoepomo, 2005). Tanaman lawang cocok tumbuh di daerah yang memiliki iklim sub-tropis. Meskipun demikian, tanaman lawang dapat tumbuh di tempat yang bukan habitatnya, hanya saja pertumbuhannya tidak semaksimal di habitat aslinya.

Oleh karena itu pertanaman lawang tersebar hingga ke wilayah beriklim tropis seperti Indonesia. tanaman lawang dapat tumbuh dengan baik jika kebutuhan air sudah tercukupi, sehingga lebih cocok pada wilayah dataran tinggi. Suhu dan kadar air yang cukup dibutuhkan sehingga perlu upaya lebih untuk dapat menanam tanaman lawang di wilayah dataran rendah. Tanaman lawang dapat tumbuh pada ketinggian 200-1.600 meter di atas permukaan laut.

Kapulaga merupakan tanaman yang dikembangkan oleh beberapa negara di dunia seperti India, Guatemala, Pakistan, Nepal, dan Indonesia. Terdapat dua macam kapulaga yang biasa diusahakan oleh produsen di Indonesia, yaitu kapulaga Jawa/lokal dengan nama 


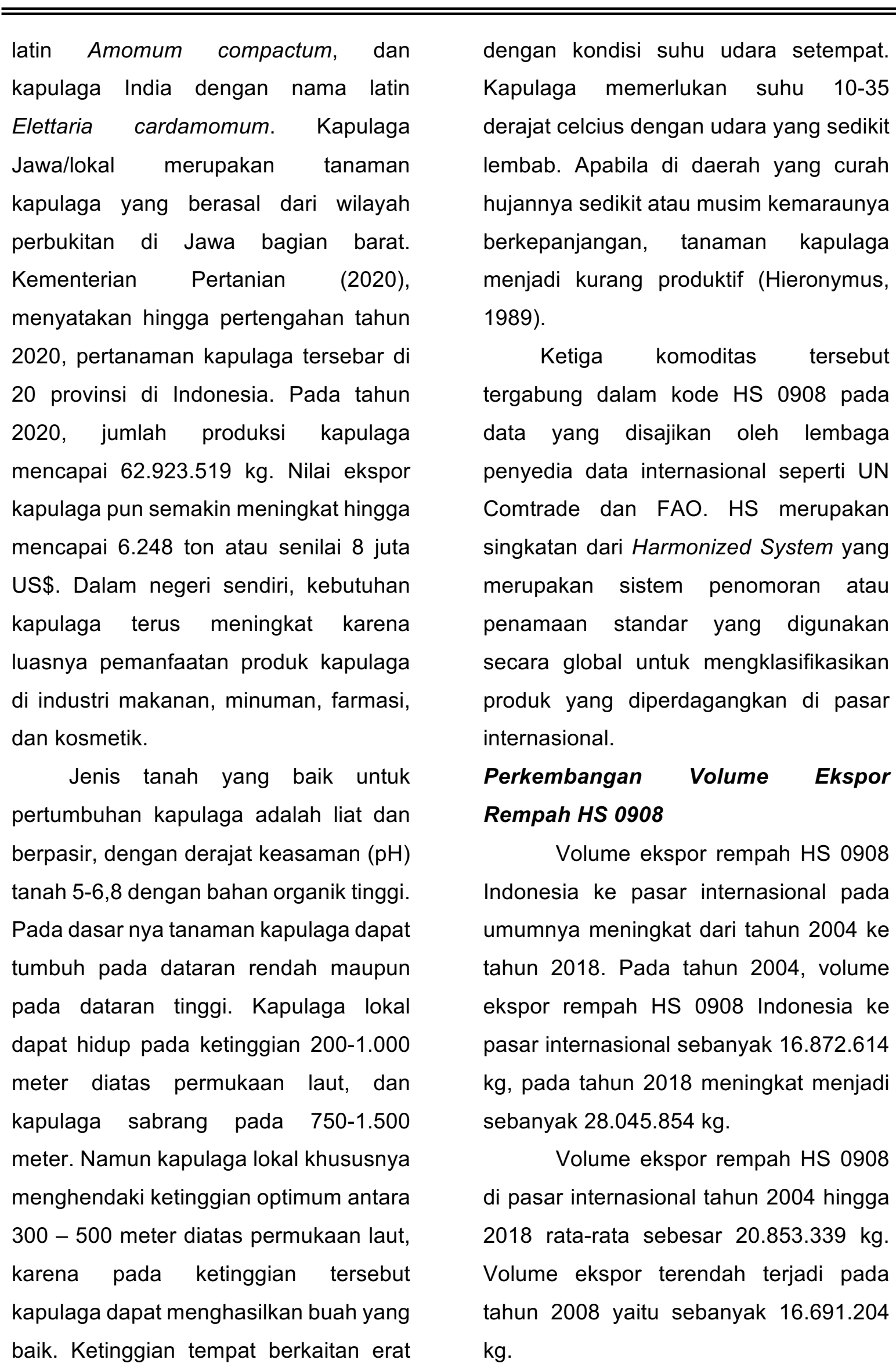


Tabel 1. Perkembangan Volume Ekspor Ekspor Rempah HS 0908 Indonesia Tahun 20042018

\begin{tabular}{|c|c|}
\hline Tahun & Volume Ekspor (Kg) \\
\hline 2004 & 16.872 .614 \\
\hline 2005 & 18.190 .670 \\
\hline 2006 & 20.170 .794 \\
\hline 2007 & 18.416 .867 \\
\hline 2008 & 16.691 .204 \\
\hline 2009 & 18.342 .329 \\
\hline 2010 & 19.813 .325 \\
\hline 2011 & 22.135 .346 \\
\hline 2012 & 21.000 .683 \\
\hline 2013 & 20.289 .644 \\
\hline 2014 & 22.477 .997 \\
\hline 2015 & 23.275 .159 \\
\hline 2016 & 19.956 .650 \\
\hline 2017 & 27.120 .943 \\
\hline 2018 & 28.045 .854 \\
\hline Rata-rata & 20.853 .339 \\
\hline
\end{tabular}

Sumber: FAOSTAT, 2020(data diolah).

Volume ekspor rempah HS 0908 pada tahun 2008 mengalami penurunan akibat permintaan impor yang menurun karena terjadinya krisis finansial di dunia pada tahun tersebut. Volume ekspor tertinggi terjadi pada tahun 2018, hal tersebut disebabkan oleh permintaan impor rempah HS 0908 yang meningkat.

Peningkatan permintaan tersebut disebabkan oleh penggunaan rempah HS 0908 yang semakin berkembang, selain digunakan untuk bahan tambahan makanan, juga mulai banyak digunakan untuk pengawet makanan kaleng, produk herbal, bahan baku obat dalam bidang farmasi, bahan tambahan dalam pembuatan parfum, aromaterapi, sabun, hingga digunakan dalam produk kosmetik.

\section{Nilai Ekspor Rempah HS 0908 Indonesia di Pasar Internasional}

Pada umumnya, nilai ekspor rempah HS 0908 Indonesia meningkat dari tahun 2004 ke tahun 2018. Tahun 2004, nilai ekspor rempah HS 0908 Indonesia sebesar US\$ 42.827.008, dan pada tahun 2018 meningkat menjadi sebesar US\$ 128.181.495. Nilai ekspor rata-rata rempah HS 0908 Indonesia adalah sebesar US\$ 96.028.885.Nilai ekspor rempah HS 0908 Indonesia di pasar internasional mencapai nilai tertinggi pada tahun 2012 yaitu senilai US\$ 156.995.090. Tingginya nilai ekspor rempah HS 0908 Indonesia di tahun 2012 disebabkan oleh permintaan yang cukup tinggi dibarengi oleh harga jual yang tinggi dengan volume ekspor $21.000 .683 \mathrm{~kg}$. 
Nilai ekspor rempah HS 0908 terendah Indonesia terdapat pada tahun 2004 yaitu US\$ 42.827.008. Nilai ekspor rendah terjadi karena permintaan ekspor yang masih rendah sehingga volume ekspor rempah HS 0908 yaitu sebanyak 16.872.614 kg dengan harga ekspor yang cukup rendah pula.

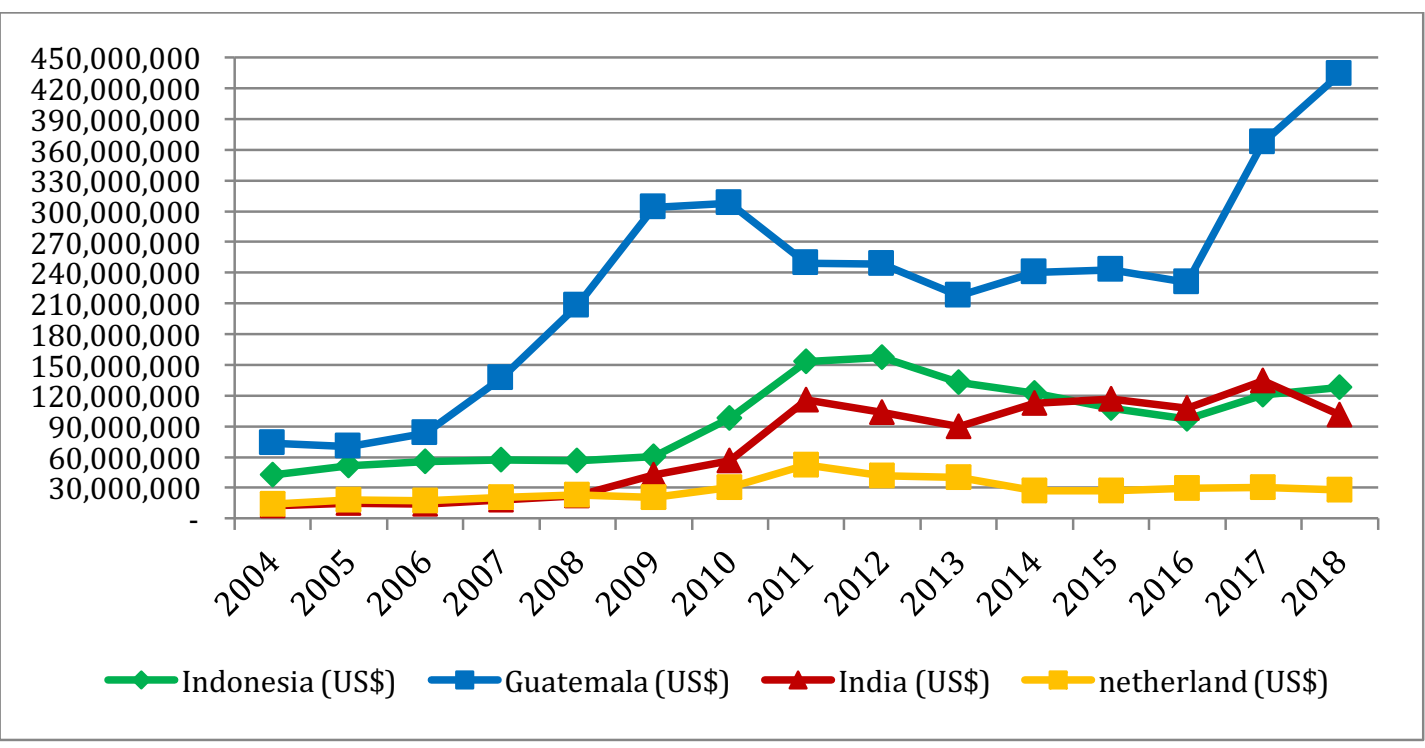

Gambar 3. Nilai Ekspor rempah HS 0908 Indonesia di Pasar Internasional

Tahun 2004-2018

Sumber: UN-Comtrade, 2021

Pada tahun 2013 hingga tahun 2016, nilai ekspor rempah HS 0908 Indonesia secara berturut-turut mengalami penurunan. Hal tersebut diakibatkan oleh produk rempah HS 0908 Indonesia yang kurang memenuhi standar kesehatan khususnya berkaitan dengan batas maksimum kandungan aflatoksin yang telah ditetapkan oleh Uni Eropa. Hal tersebut diperparah oleh perlambatan ekonomi dunia yang terjadi pada tahun 2015 dan 2016 yang mempengaruhi penurunan permintaan komoditas tersebut di pasar internasional.

Selama periode 2004 hingga 2018, Indonesia rata-rata menempati posisi kedua sebagai negara eksportir rempah HS 0908 terbesar dengan nilai ekspor rata-rata sebesar US\$ 96.028.885. Posisi pertama negara eksportir rempah HS 0908 selama 20042018 diduduki oleh Negara Guatemala. Hal tersebut disebabkan oleh volume ekspor rempah HS 0908 Guatemala lebih tinggi dibandingkan volume ekspor Indonesia yaitu sebanyak $31.116 .514 \mathrm{~kg}$. Harga ekspor rempah HS 0908 Guatemala pun lebih tinggi dibanding Indonesia. Sehingga Guatemala memiliki nilai ekspor rata-rata sebesar US\$ 227.648.816.

Posisi ketiga negara eksportir rempah HS 0908 diduduki oleh Negara 


\section{Jurnal Agristan}

Vol. 3 No. 2 - November 2021

India dengan nilai ekspor rata-rata sebesar US\$ 70.845.192 dan volume ekspor rata-rata sebanyak $7.287 .605 \mathrm{~kg}$. Pada tahun 2015 hingga 2017, India menduduki posisi kedua sebagai eksportir rempah HS 0908 terbesar, hal tersebut terjadi karena volume ekspor rempah HS 0908 India yang meningkat dibarengi oleh penurunan harga ekspor rempah HS 0908 Indonesia. Netherland menjadi negara eksportir rempah HS 0908 yang menduduki posisi keempat dengan nilai ekspor rata-rata US\$ 27.965.495 dan volume ekspor rata-rata sebanyak $2.436 .473 \mathrm{~kg}$.

Nilai Ekspor Total Indonesia ke Pasar Internasional
Pada umumnya, nilai ekspor total Indonesia ke pasar internasional meningkat dari tahun 2004 ke tahun 2018. Tahun 2004, nilai ekspor total Indonesia sebesar US\$ 71.582.468.122, dan pada tahun 2018 meningkat menjadi sebesar US\$ 180.215.034.437. Nilai ekspor ratarata Indonesia adalah sebesar US\$ 145.296.599.065. Nilai ekspor total Indonesia mencapai nilai tertinggi pada tahun 2011 yaitu sebesar US\$ 203.496.619.185. Hal tersebut diakibatkan oleh peningkatan kinerja ekspor khususnya non-migas Indonesia. Sedangkan nilai ekspor total terendah Indonesia terdapat pada tahun 2004 yaitu senilai US\$ 71.582.468.122.

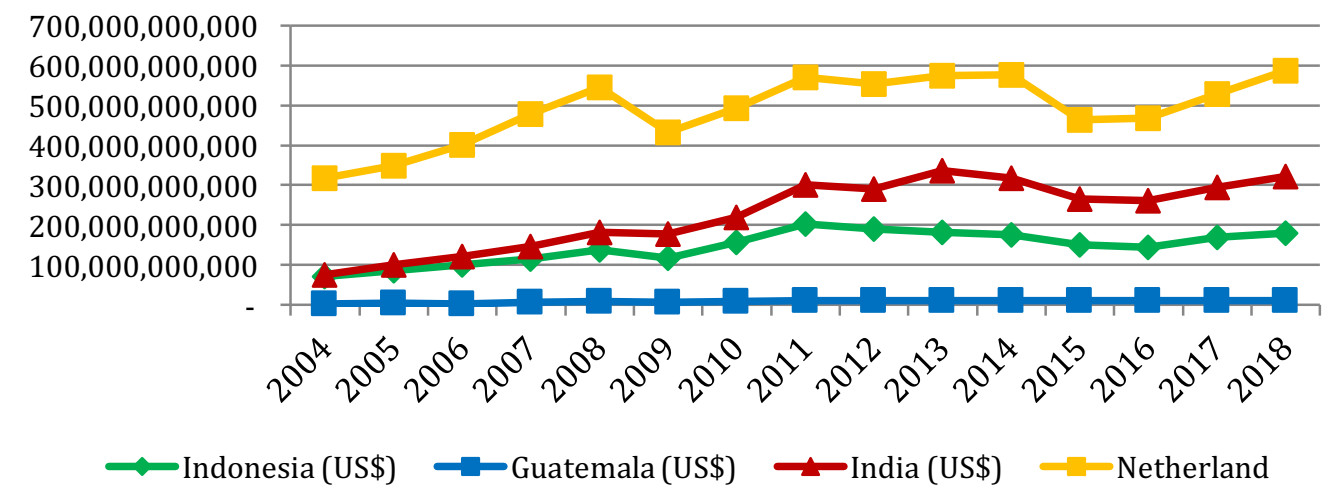

Gambar 4. Nilai Ekspor Total Indonesia di Pasar Internasional Tahun 2004-2018 Sumber: UN-Comtrade, 2021.

Pada tahun 2009, Indonesia sempat mengalami penurunan nilai ekspor total sebagai dampak dari krisis finansial yang terjadi di dunia. Selain itu, Indonesia mengalami penurunan nilai ekspor di tahun 2012 hingga tahun 2016. Hal tersebut merupakan dampak dari peristiwa commodity boom yang terjadi pada tahun 2011 kemudian diperparah oleh perlambatan ekonomi global yang terjadi pada tahun 2015 dan 2016.

Negara Indonesia menjadi negara dengan nilai ekspor total tertinggi ketiga apabila dibandingkan dengan Negara 
Netherland, Guatemala dan India. Netherland menjadi negara dengan nilai ekspor total tertinggi. Nilai ekspor total Netherland selama 15 tahun dari tahun 2004 sampai dengan 2018 rata-rata sebesar US\$ 489.167.069.922. Negara dengan nilai ekspor total tertinggi kedua yaitu Negara India. Nilai ekspor total India selama 15 tahun dari tahun 2004 sampai dengan 2018 rata-rata sebesar US\$ 227.277.232.257. Guatemala berada di posisi keempat dengan nilai ekspor rata-rata sebesar US\$ 8.413.085.056.

\section{Nilai Ekspor Total Rempah HS 0908 di} Pasar Internasional

Nilai ekspor total rempah HS 0908 ke pasar internasional adalah jumlah nilai dari kegiatan ekspor yang dilakukan oleh negara produsen rempah HS 0908. Nilai ekspor total rempah HS 0908 di pasar internasional didapatkan dari penjumlahan nilai ekspor yang dilakukan oleh 56 negara eksportir rempah HS 0908 yang secara rutin melakukan pelaporan kegiatan ekspor pada United Nations of Commodity Trade Database (UN-Comtrade) selama periode 2004-2018.

Nilai ekspor rempah HS 090856 negara tersebut memberikan kontribusi rata-rata sebesar 89,43 persen terhadap ekspor total rempah HS 0908 di pasar internasional. Berdasarkan Gambar 5 nilai ekspor total rempah HS 0908 di pasar internasional mengalami kenaikan dari tahun 2004 ke tahun 2018. Pada tahun 2004, nilai ekspor total rempah HS 0908 adalah sebesar US\$ 171.607.677, dan tahun 2018 sebesar US\$ 822.619.130. Selama tahun 2004 hingga 2018 rata-rata sebesar US\$ 496.784.676.

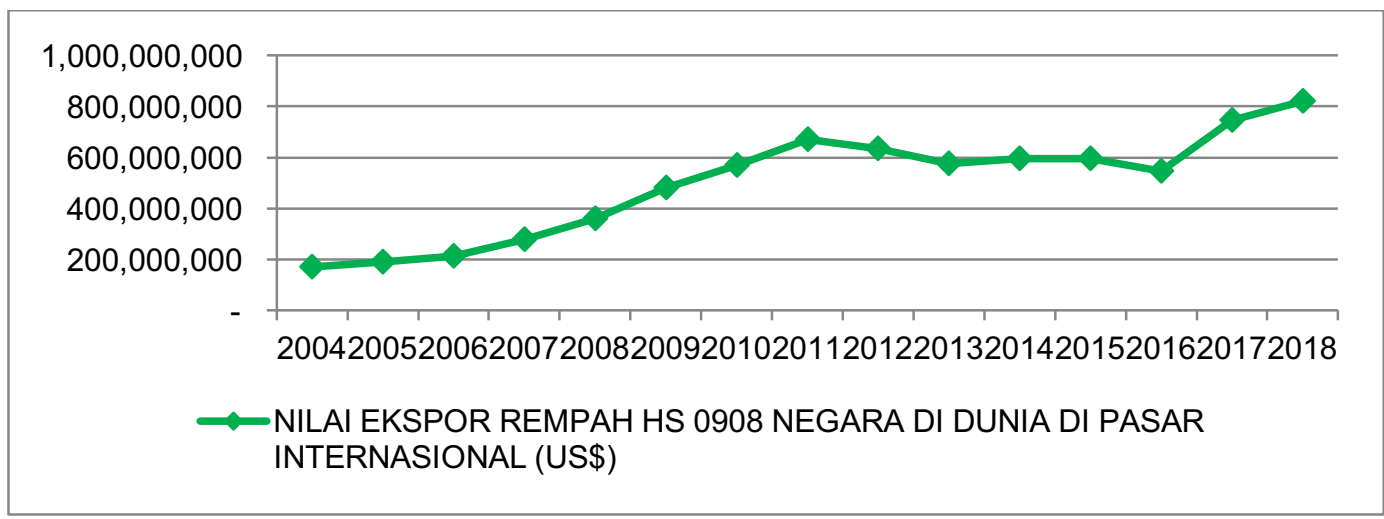

Gambar 5. Nilai Ekspor Total Rempah HS 0908 Dunia di Pasar Internasional Tahun 2004-2018

Sumber: UN-Comtrade, 2021

Nilai ekspor total mencapai nilai tertinggi pada tahun 2018 yaitu senilai
US\$ 822.619.130. Hal tersebut karena permintaan rempah HS 0908 yang terus 
Vol. 3 No. 2 - November 2021

meningkat sehingga menyebabkan terjadinya peningkatkan nilai ekspor sebagian negara eksportir rempah HS 0908. Nilai ekspor total rempah HS 0908 dunia pun meningkat. Nilai ekspor total terendah terdapat pada tahun 2004 yaitu senilai US\$ 171.607.677. Hal tersebut disebabkan oleh permintaan rempah HS 0908 yang masih rendah sehingga nilai ekspor negara-negara eksportir rempah HS 0908 pun masih rendah dibandingkan tahun-tahun lainnya selama periode 2004-2018.

\section{Nilai Ekspor Total Negara di Dunia}

Nilai ekspor total negara di dunia adalah jumlah total dari nilai ekspor seluruh komoditas (termasuk komoditas rempah HS 0908) di dunia ke pasar internasional. Nilai ekspor total di dunia didapat dari penjumlahan nilai ekspor total yang dilakukan oleh 126 negara eksportir di dunia yang secara rutin melakukan pelaporan kegiatan ekspornya pada United Nations of Commodity Trade Database (UN-Comtrade) dalam periode 2004-2018. Nilai ekspor total dari 126 negara tersebut memberikan kontribusi rata-rata sebesar 96,93 persen terhadap ekspor total di dunia.

Berdasarkan Gambar 6 nilai ekspor total negara di dunia ke pasar internasional mengalami kenaikan dari tahun 2004 ke tahun 2018. Pada tahun 2004, nilai ekspor total negara di dunia adalah sebesar US\$ 8.782.370.700.788, dan tahun 2018 sebesar US\$ 18.630.280.879.527. Selama tahun 2004 hingga 2018 rata-rata nilai ekspor total di dunia adalah sebesar US\$ 14.923.074.497.969.

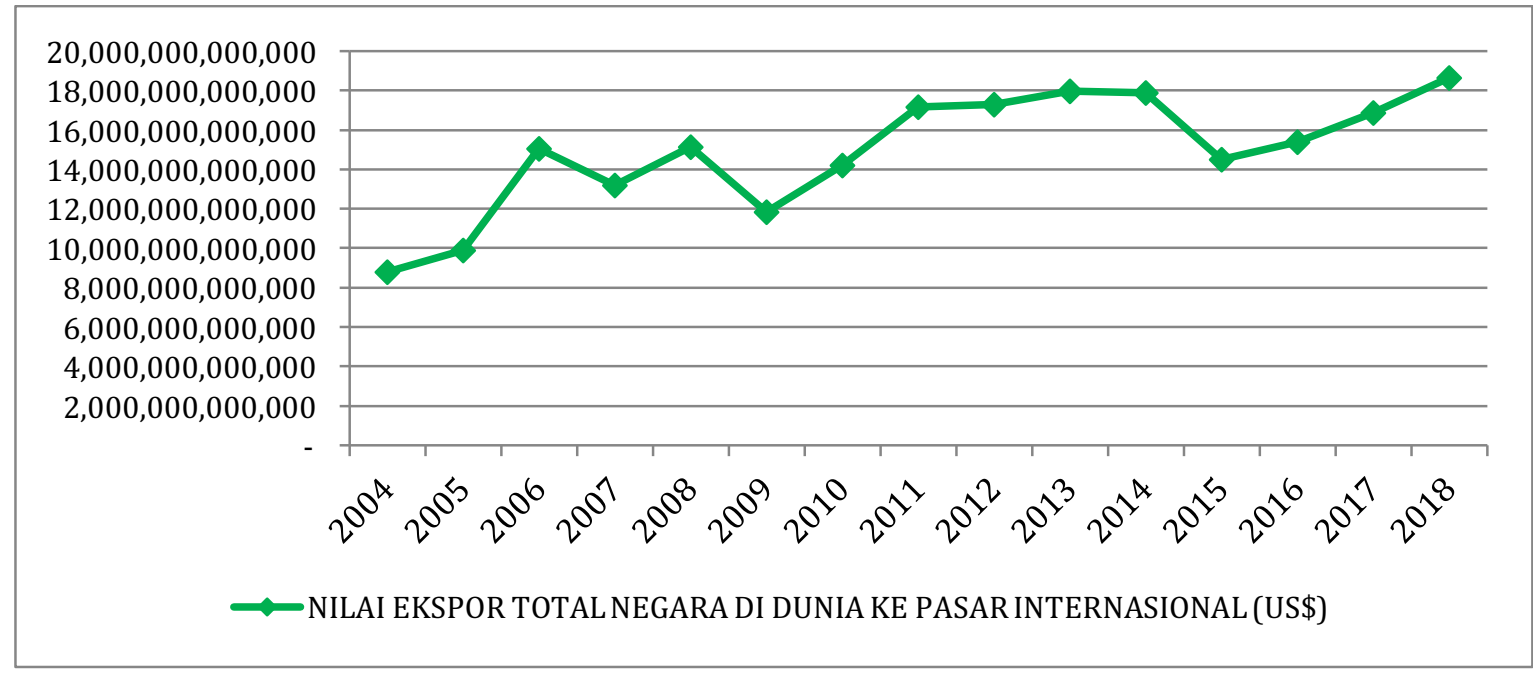

Gambar 6. Nilai Ekspor Total Negara di Dunia di Pasar Internasional Tahun 2004-2018 Sumber: UN-Comtrade, 2021 yaitu senilai US\$ 18.630.280.879.527.

Nilai ekspor total di dunia mencapai nilai tertinggi pada tahun 2018
Hal tersebut karena peningkatan aktivitas ekonomi khususnya dalam kegiatan 
ekspor impor negara di dunia sehingga menyebabkan peningkatan nilai ekspor total. Nilai ekspor total di dunia terendah terdapat pada tahun 2004 yaitu senilai US\$ 8.782.370.700.788. Hal tersebut disebabkan oleh aktivitas ekspor impor yang masih terbatas sehingga nilai ekspor total di dunia masih rendah dibandingkan tahun-tahun lainnya selama periode 2004-2018.

Nilai Impor Rempah HS 0908 Indonesia

Berdasarkan Gambar 7, nilai impor rempah HS 0908 Indonesia mengalami kenaikan dari tahun 2004 ke tahun 2018. Pada tahun 2004, nilai impor Indonesia adalah sebesar US\$107.950, dan tahun 2018 sebesar US\$ 3.124.624.

Selama tahun 2004 hingga 2018 rata-rata nilai impor rempah HS 0908 Indonesia adalah sebesar US\$ 973.525.

Nilai impor rempah HS 0908 Indonesia mencapai nilai tertinggi pada tahun 2018 yaitu senilai US\$3.124.624. Nilai impor rempah HS 0908 yang tinggi disebabkan oleh kenaikan permintaan domestik akibat dari penggunaan rempah HS 0908 di Indonesia yang semakin berkembang sehingga menyebabkan tingginya kenaikan volume impor pada tahun tersebut, yaitu menjadi sebanyak $3.124 .624 \mathrm{~kg}$.

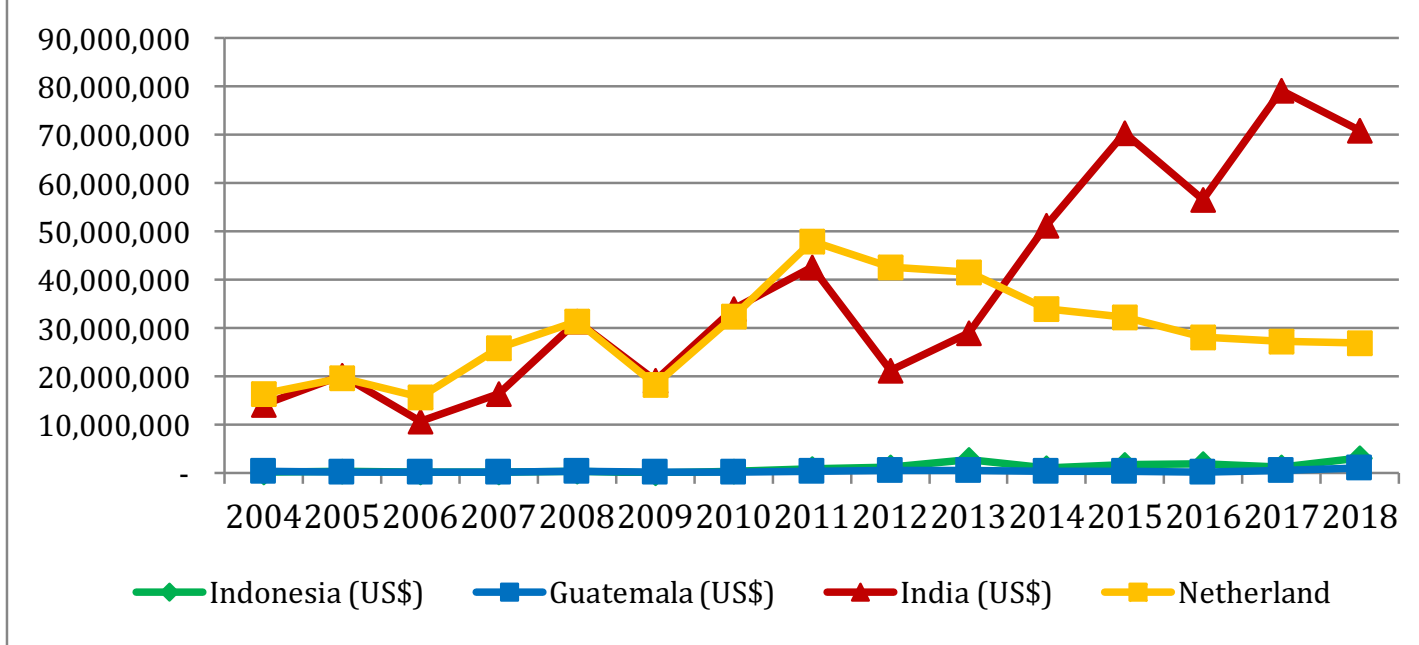

Gambar 7. Nilai Impor rempah HS 0908 Indonesia di Pasar Internasional Tahun 2004-2018

Sumber: UN-Comtrade, 2021.

Nilai impor rempah HS 0908 terendah di Indonesia terdapat pada tahun 2009 yaitu senilai US\$36.675. Hal tersebut karena krisis finansial yang terjadi secara global yang berpengaruh terhadap penurunan permintaan produk di Indonesia sehingga menyebabkan volume impor rempah HS 0908 pada 
tahun tersebut cukup rendah yaitu sebanyak $18.812 \mathrm{~kg}$. volume impor pada tahun 2009 pun menjadi volume impor terendah untuk Indonesia selama periode 2004-2018.

Negara Indonesia menjadi negara dengan nilai impor rempah HS 0908 tertinggi ketiga apabila dibandingkan dengan Negara Netherland, Guatemala dan India. Negara India menduduki posisi pertama sebagai negara dengan nilai impor rempah HS 0908 tertinggi. Nilai impor India selama 15 tahun dari tahun 2004 sampai dengan 2018 rata-rata sebesar US\$ 37.764 .283 dengan volume impor sebanyak $6.114 .573 \mathrm{~kg}$. Negara dengan nilai impor rempah HS 0908 tertinggi kedua adalah Negara Netherland. Nilai impor rempah HS 0908 Netherland selama 15 tahun dari tahun 2004 sampai dengan 2018 rata-rata sebesar US\$ 29.323.600, dengan volume impor sebanyak $3.276 .010 \mathrm{~kg}$. Guatemala berada di posisi keempat dengan nilai impor rempah HS 0908 rata-rata sebesar US\$ 307.770 dan volume ekspor sebanyak $132.033 \mathrm{~kg}$.

\section{Daya Saing Indonesia berdasarkan} Posisi Perdagangan Rempah HS 0908 di Pasar Internasional

Indeks Spesialisasi Perdagangan

(ISP) digunakan untuk menganalisis posisi dan atau tahapan perkembangan produk rempah HS 0908 melihat dari sisi permintaan dan penawaran. Nilai ISP ini akan menggambarkan apakah Negara Indonesia memiliki kecenderungan sebagai negara eksportir atau negara importir rempah HS 0908. Indeks ISP ini dipengaruhi oleh permintaan dan penawaran, dimana ekspor mencerminkan suplai domestik dan impor mencerminkan permintaan domestik.

Hubungan nilai ekspor dan impor dengan daya saing menurut Tambunan (2001) apabila suatu negara mempunyai daya saing yang lebih tinggi daripada negara lain untuk jenis komoditas atau produk yang sama, maka suatu negara cenderung menjadi pengekspor komoditas atau produk yang bersangkutan, namun apabila suatu negara cenderung menjadi pengimpor maka daya saingnya akan rendah.

\section{Indeks Spesialisasi Perdagangan Indonesia}

Berdasarkan analisis Gambar 8, nilai Indeks Spesialisasi Perdagangan rempah HS 0908 Indonesia selama periode 2004-2018 selalu menunjukkan nilai positif (lebih dari 0) dengan rata-rata nilai ISP sebesar 0,983 . Nilai tersebut dapat diartikan bahwa suplai domestik lebih tinggi daripada permintaan domestik sehingga Indonesia memiliki kecenderungan berperan sebagai eksportir untuk rempah HS 0908 di pasar internasional. 
Sejauh ini, kedudukan Indonesia sebagai eksportir rempah HS 0908 cukup kuat, dilihat dari nilai ISP yang berada diatas 0,9. Meskipun demikian, nilai ISP rempah HS 0908 Indonesia pada umumnya mengalami penurunan dari tahun 2004 ke tahun 2018. Pada tahun 2004, nilai ISP rempah HS 0908 sebesar 0,995 dan tahun 2018 menurun menjadi sebesar 0,952. Nilai ISP tertinggi terdapat pada tahun 2009 yakni sebesar 0,999. Hal tersebut disebabkan oleh permintaan domestik rempah HS 0908 yang rendah dengan nilai impor rempah HS 0908 sebesar US\$ 36.675 dan volume impor sebesar $18.812 \mathrm{~kg}$. Nilai impor yang rendah tersebut salah satunya dipengaruhi oleh krisis finansial yang terjadi secara global pada tahun tersebut sehingga menyebabkan permintaan rempah HS 0908 di Indonesia mengalami penurunan.

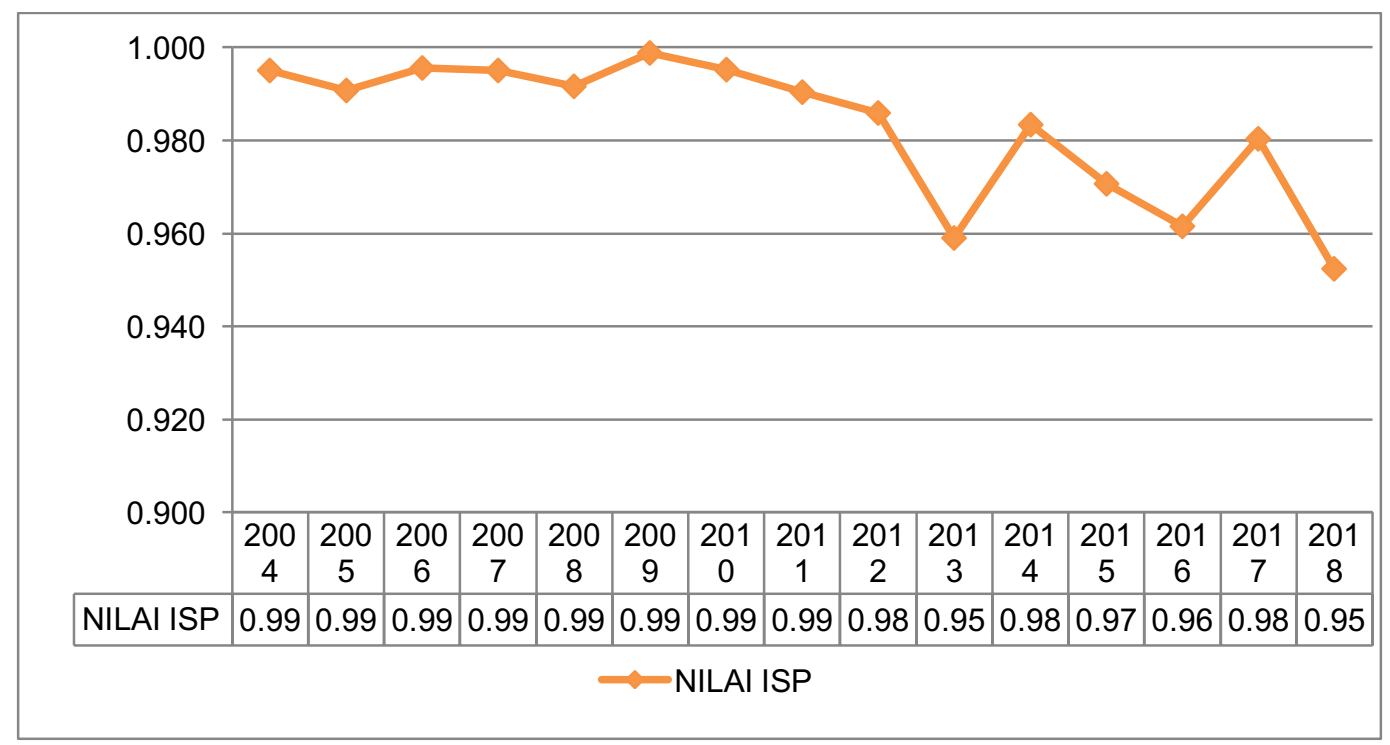

Gambar 8. Nilai ISP rempah HS 0908 Indonesia Tahun 2004-2018

Sumber: UN Comtrade (diolah), 2021.

Nilai dan volume impor terendah

bagi Indonesia selama periode 20042018 terjadi pada tahun 2009. Meskipun pada tahun 2009 terjadi krisis finansial di dunia, harga rempah HS 0908 Indonesia di beberapa negara masih cukup tinggi

sehingga nilai ekspor rempah HS 0908 pada tahun 2009 pun meningkat dari tahun sebelumnya, yaitu sebesar US\$
60.425.609 dengan volume ekspor $18.342 .329 \mathrm{~kg}$.

Nilai indeks spesialisasi perdagangan terendah rempah HS 0908 Indonesia selama periode 2004-2018 terjadi pada tahun 2018 yakni 0,952 . Hal tersebut disebabkan oleh semakin berkembangnya produsen-produsen yang memanfaatkan rempah HS 0908 di Indonesia sehingga berdampak pada 
kenaikan permintaan impor dan menyebabkan kenaikan nilai impor bagi Negara Indonesia yakni menjadi sebesar US\$ 3.124.624 dengan volume impor sebanyak $652.860 \mathrm{~kg}$. Nilai dan volume impor tersebut merupakan nilai dan volume impor tertinggi selama periode 2004 hingga 2018.

Selain tahun 2018, Indonesia mengalami penurunan nilai ISP yang cukup besar tahun 2013 dan 2016. Nilai ISP tahun 2013 yang rendah diakibatkan oleh penurunan nilai ekspor rempah HS 0908 Indonesia yaitu menjadi sebesar US\$ 133.101.147 dengan volume ekspor sebanyak 20.289.644 kg. Penurunan tersebut terjadi akibat sebagian dari rempah HS 0908 Indonesia yang tidak lolos ekspor karena kurang memenuhi standar kesehatan khususnya yang ditetapkan oleh Uni Eropa, dimana pada tahun tersebut diberlakukan pembatasan kandungan aflatoksin pada rempah HS 0908 yang diekspor ke Uni Eropa.

Sedangkan rempah HS 0908 Indonesia ini masih memiliki kandungan aflatoksin yang lebih tinggi dari standar yang telah ditetapkan yaitu sekitar 6,4$120 \mu \mathrm{g}$ per gram aflatoksin $\mathrm{BI}$, dengan aflatoksin total 10,1-140 $\mu \mathrm{g}$ per gram. Sedangkan batas maksimal yang ditetapkan oleh Uni Eropa adalah sebanyak $5 \mu \mathrm{g}$ per gram untuk aflatoksin B1 dan aflatoksin total $10 \mu \mathrm{g}$ per gram. Penurunan nilai ekspor tersebut dibarengi oleh kenaikan nilai impor yang tinggi yakni menjadi sebesar US\$ 2.781.273.

Pada tahun 2016, nilai ISP Indonesia mengalami menurun akibat terjadinya penurunan nilai ekspor rempah HS 0908 yakni sebesar US\$ 96.672.299. Hal tersebut disebabkan oleh penurunan permintaan rempah HS 0908 Indonesia sebagai akibat dari terjadinya perlambatan ekonomi dunia pada tahun tersebut. Dilihat dari nilai ISP Indonesia yang berada pada kisaran 0,952 hingga 0,999 , mengindikasikan bahwa Indonesia merupakan net exporter yang berada pada tahap kedewasaan. Hal tersebut menggambarkan bahwa Indonesia memiliki daya saing yang cukup tinggi pada komoditas rempah HS 0908.

Perbandingan ISP rempah HS 0908 Indonesia, Guatemala, India, dan Netherland

Hasil perhitungan ISP dari masing-masing negara produsen rempah HS 0908 selama periode 2004 hingga 2018 terdapat pada Tabel 2.

Hasil perhitungan ISP dari masing-masing negara produsen rempah HS 0908 selama periode 2004 hingga 2018 menunjukkan perbedaan nilai yang signifikan. Indonesia menjadi negara dengan daya saing tertinggi kedua setelah Guatemala. Nilai ISP Guatemala berkisar antara 0,991 hingga 0,999 dengan rata-rata sebesar 0,997 . Nilai ISP 
tersebut memberikan gambaran bahwa

sebagai eksportir rempah HS 0908 dan

Guatemala memiliki kecenderungan

berada pada tahap kedewasaan.

Tabel 2. Perbandingan Nilai ISP Indonesia, Guatemala, India, dan Netherland

\begin{tabular}{lrrrr}
\hline \multirow{2}{*}{ Tahun } & \multicolumn{4}{c}{ ISP } \\
\cline { 2 - 5 } & Indonesia & Guatemala & \multicolumn{1}{l}{ India } & Netherland \\
\hline 2004 & 0,995 & 0,991 & $-0,062$ & $-0,070$ \\
2005 & 0,991 & 0,997 & $-0,155$ & $-0,038$ \\
2006 & 0,996 & 0,997 & 0,146 & 0,048 \\
2007 & 0,995 & 0,998 & 0,047 & $-0,121$ \\
2008 & 0,992 & 0,998 & $-0,170$ & $-0,144$ \\
2009 & 0,999 & 0,999 & 0,377 & 0,066 \\
2010 & 0,995 & 0,999 & 0,250 & $-0,029$ \\
2011 & 0,990 & 0,998 & 0,463 & 0,040 \\
2012 & 0,986 & 0,996 & 0,660 & $-0,011$ \\
2013 & 0,959 & 0,996 & 0,514 & $-0,020$ \\
2014 & 0,983 & 0,997 & 0,374 & $-0,118$ \\
2015 & 0,971 & 0,998 & 0,248 & $-0,088$ \\
2016 & 0,961 & 0,998 & 0,312 & 0,024 \\
2017 & 0,980 & 0,998 & 0,259 & 0,047 \\
2018 & 0,952 & 0,995 & 0,176 & 0,021 \\
rata-rata & $\mathbf{0 , 9 8 3}$ & $\mathbf{0 , 9 9 7}$ & $\mathbf{0 , 2 2 9}$ & $\mathbf{0 , 0 2 6}$ \\
\hline
\end{tabular}

Sumber: UN Comtrade (diolah), 2021.

Nilai ISP Guatemala yang tinggi

India sedikit lebih besar dari permintaan membuat Guatemala menjadi negara domestiknya sehingga India memiliki yang memiliki daya saing tertinggi dibandingkan Indonesia, India, dan Netherland. Nilai ISP Guatemala yang tinggi disebabkan oleh penawaran (ekspor) yang tinggi dibarengi oleh permintaan (impor) yang cukup rendah. Harga ekspor dari rempah HS 0908 Guatemala pun tinggi sehingga nilai ekspor rempah HS 0908 Guatemala tinggi. India menduduki posisi ketiga dengan nilai ISP rata-rata sebesar 0,229. Nilai tersebut menunjukkan bahwa penawaran domestik rempah HS 0908 kecenderungan sebagai eksportir yang berada pada tahap pertumbuhan. Di India, rempah HS 0908 ini merupakan salah satu komoditas yang selalu diperlukan dalam keseharian masyarakatnya sehingga menyebabkan permintaan domestik rempah HS 0908 tinggi. Hal ini menjadi alasan selisih penawaran domestik dan permintaan domestiknya rendah.

Netherland merupakan negara eksportir rempah HS 0908 tertinggi di wilayah Eropa dan merupakan negara 
eksportir rempah HS 0908 tertinggi keempat di dunia, namun nilai rata-rata ISP Netherland adalah sebesar -0,026. Nilai tersebut menunjukkan bahwa Netherland tidak berdaya saing dibandingkan Indonesia, Guatemala, dan India. Netherland pun memiliki kecenderungan sebagai importir serta berada pada tahap substitusi impor. Hal tersebut disebabkan oleh status Netherland yang bukan merupakan produsen yang memproduksi rempah $\mathrm{HS}$ 0908 secara mandiri di negaranya, melainkan hasil dari kegiatan impor yang dilakukan. Netherland mengimpor rempah HS 0908 dalam jumlah besar, yang sebagian digunakan untuk memenuhi kebutuhan dalam negeri dan sisanya diekspor ke negara lain terutama negara-negara di Uni Eropa setelah mendapatkan perlakuan tambahan untuk meningkatkan nilai tambah rempah $\mathrm{HS}$ 0908 tersebut.

Daya Saing berdasarkan Keunggulan Komparatif rempah HS 0908 Indonesia di Pasar Internasional

Suatu negara dapat
dikategorikan mempunyai daya saing
jika negara tersebut mampu
menghasilkan rempah HS 0908 dengan
keunggulan komparatif yang tinggi

dibanding negara pesaing. Keunggulan komparatif perdagangan rempah HS 0908 Indonesia diukur dengan Revealed Comparative Advantage (RCA). Konsep analisis RCA ini membandingkan tentang nilai ekspor komoditas terkait terhadap total ekspor negara produsen dengan nilai ekspor komoditas terkait dalam perdagangan dunia. Jika nilai RCA menunjukkan nilai lebih dari satu, maka rempah HS 0908 negara Indonesia dianggap memiliki daya saing. Semakin tinggi nilai RCA, semakin kuat pula daya saing rempah HS 0908 Negara Indonesia di pasar internasional.

\section{Revealed Comparative Advantage} (RCA) Indonesia

Berdasarkan analisis Revealed Comparative Advantage (RCA) Gambar 9, rempah HS 0908 Indonesia memiliki nilai rata-rata RCA sebesar 21,597 selama periode 2004-2018, sehingga rempah HS 0908 Indonesia memiliki keunggulan komparatif di pasar internasional karena RCA $>1$, yang berarti bahwa Indonesia mampu berdaya saing dengan negara lain pada komoditas rempah HS 0908. Meskipun demikian, nilai RCA rempah HS 0908 Indonesia pada umumnya mengalami penurunan dari tahun 2004 ke tahun 2018. 


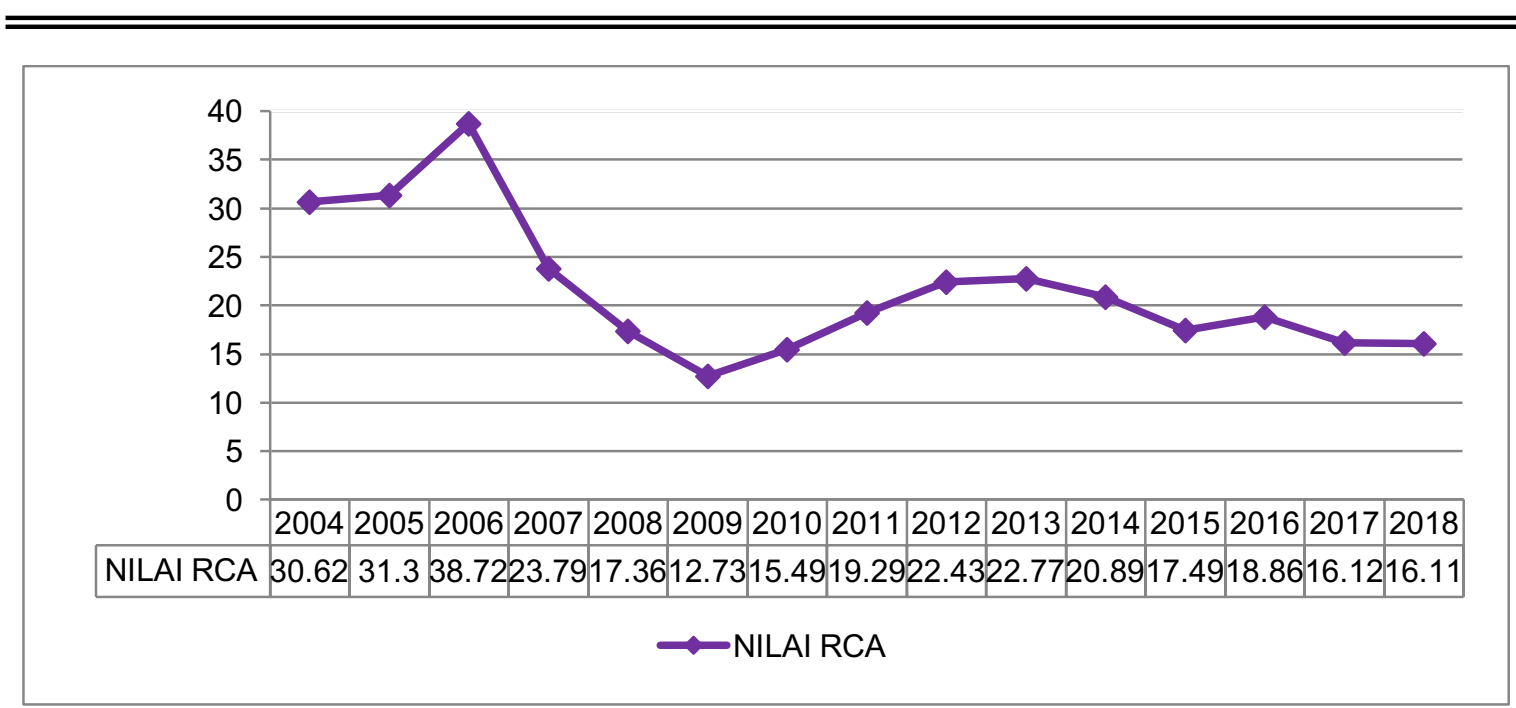

Gambar 9. Nilai RCA Komoditas Pala, Lawang, dan Kapulaga Indonesia

Tahun 2004-2018

Sumber: UN Comtrade (diolah), 2021.

karena nilai ekspor rempah HS 0908

Pada tahun 2004, nilai RCA rempah HS 0908 Indonesia sebesar 30,619 dan tahun 2018 menurun menjadi sebesar 16,108. Nilai RCA tertinggi terdapat pada tahun 2006 yakni sebesar 38,717. Hal tersebut disebabkan oleh kondisi perdagangan rempah HS 0908, dimana ekspor yang dilakukan negara eksportir rempah HS 0908 pada tahun tersebut masih belum banyak. Hal tersebut dibarengi oleh ekspor rempah HS 0908 Indonesia yang tinggi dan tetap meningkat dari tahun sebelumnya sehingga menyebabkan nilai RCA Indonesia tinggi. Daya saing tertinggi Indonesia pun dicapai pada tahun tersebut.

Nilai RCA terendah rempah HS 0908 Indonesia selama periode 20042018 terjadi pada tahun 2009 yakni sebesar 12,727. Hal tersebut terjadi sebagian negara mengalami peningkatan yang cukup tinggi yang menyebabkan nilai ekspor total di dunia mengalami kenaikan yang besar, sehingga meskipun ekspor rempah HS 0908 Indonesia meningkat, nilai RCA Indonesia mengalami penurunan

Perbandingan RCA Rempah HS 0908 Indonesia, Guatemala, India, dan Netherland

Berdasarkan hasil perhitungan pada tabel 3, Negara Indonesia, Guatemala, India, dan Netherland mempunyai nilai RCA lebih dari satu. Menurut Tambunan (2004) apabila nilai RCA lebih besar dari satu, maka negara tersebut memiliki keunggulan komparatif untuk komoditas tersebut. Sebaliknya jika nilai RCA lebih kecil dari satu berarti negara tersebut tidak memiliki keunggulan komparatif. 


Guatemala menjadi negara
dengan daya saing tertinggi pada
rempah HS 0908 di pasar internasional,
kemudian disusul oleh Negara
Indonesia. Hal tersebut dilihat dari nilai
RCA rata-rata rempah HS 0908 Negara
Guatemala sebesar 885,830 Nilai
tersebut jauh lebih tinggi dari nilai RCA
rata-rata Indonesia sebesar $21,597$.
India menduduki posisi ketiga dengan
nilai RCA rata-rata sebesar 8,404,
kemudian disusul oleh Netherland
dengan nilai RCA rata-rata sebesar
1,872 .

Nilai RCA Guatemala yang tinggi diperoleh karena harga ekspor rempah HS 0908 Guatemala yang tinggi, hingga mencapai dua kali lipat harga ekspor rempah HS 0908 Indonesia, juga dibarengi oleh volume ekspor Guatemala yang lebih banyak dibandingkan Indonesia. Hal tersebut membuat Guatemala menduduki posisi negara dengan daya saing tertinggi pada rempah HS 0908 di pasar internasional. Harga ekspor rempah HS 0908 Guatemala yang lebih tinggi disebabkan oleh kualitas rempah HS 0908 Guatemala yang lebih baik, salah satunya berkaitan dengan kandungan aflatoksin dimana rempah HS 0908 Guatemala ini telah cukup memenuhi standar yang telah ditetapkan oleh importir seperti Uni Eropa. Kualitas yang baik tersebut tentu diperoleh dari penerapan Standar Operasional Prosedur (SOP) yang baik di negara Guatemala, dimana dalam pelaksanaannya pemanenan dilakukan saat rempah HS 0908 telah masak, sedangkan di Indonesia masih ada banyak produsen yang memanen rempah HS 0908 ini sebelum waktunya sehingga hal tersebut berpengaruh pada kualitas produk yang akan dijual.

Selain itu, pengeringan telah dilakukan dengan menggunakan alat sehingga lebih efektif dengan kadar air yang telah terukur dan sesuai dengan standar yang ada yaitu dibawah 12 persen. Proses penanganan rempah HS 0908 pun dilakukan dengan lebih hati-hati untuk menghindari terjadinya kontaminasi yang dapat menyebabkan kualitas rempah HS 0908 menurun. Berbeda dengan Indonesia yang masih melakukan pengeringan produk dengan memanfaatkan cahaya matahari dan dihamparkan begitu saja tanpa memperhatikan kemungkinan kontaminasi yang dapat terjadi. Kadar air dari rempah HS 0908 pun tidak selalu sesuai dengan standar yang ada.

Dari segi kuantitas, Guatemala dapat menghasilkan rempah HS 0908 lebih banyak pada lahan yang lebih sempit dari Indonesia. Berdasarkan data yang ada, luas lahan Guatemala rata-rata 72.511 Ha pada periode 2004-2018 dengan jumlah produksi rata-rata sebesar 
31.657 ton per tahun. Sedangkan jumlah produksi rempah HS 0908 Indonesia rata-rata sebesar 25.596 ton per tahun pada luas lahan produksi rata-rata $119.697 \mathrm{Ha}$. Hal tersebut terjadi karena di Guatemala, rempah HS 0908 ini telah di produksi secara lebih intensif mulai dari penggunaan benih varietas unggul, pemeliharaan yang baik selama proses produksi, hingga pemanenan dan penanganan pasca panen yang cukup baik, bahkan rempah HS 0908 ini telah dijadikan sebagai salah satu produk unggulan ekspor bagi Guatemala.

Tabel 3. Perbandingan Nilai RCA Indonesia, Guatemala, India, dan Netherland

\begin{tabular}{lrrrr}
\hline Tahun & $\begin{array}{c}\text { Hasil RCA } \\
\text { Indonesia }\end{array}$ & $\begin{array}{c}\text { Hasil RCA } \\
\text { Guatemala }\end{array}$ & Hasil RCA India & $\begin{array}{c}\text { Hasil RCA } \\
\text { Netherland }\end{array}$ \\
\hline 2004 & 30,619 & $1.290,296$ & 8,383 & 2,283 \\
2005 & 31,302 & 680,163 & 7,643 & 2,705 \\
2006 & 38,717 & $1.836,270$ & 8,338 & 3,023 \\
2007 & 23,789 & 947,411 & 5,855 & 2,018 \\
2008 & 17,356 & $1.129,708$ & 5,137 & 1,804 \\
2009 & 12,727 & $1.035,000$ & 5,867 & 1,183 \\
2010 & 15,492 & 910,323 & 6,421 & 1,547 \\
2011 & 19,291 & 628,268 & 9,835 & 2,341 \\
2012 & 22,430 & 666,438 & 9,736 & 2,048 \\
2013 & 22,765 & 674,770 & 8,355 & 2,171 \\
2014 & 20,885 & 663,543 & 10,630 & 1,395 \\
2015 & 17,491 & 554,855 & 10,763 & 1,418 \\
2016 & 18,857 & 612,425 & 11,683 & 1,775 \\
2017 & 16,124 & 753,727 & 10,325 & 1,283 \\
2018 & 16,108 & 904,260 & 7,097 & 1,080 \\
TOTAL & $\mathbf{2 1 , 5 9 7}$ & $\mathbf{8 8 5 , 8 3 0}$ & $\mathbf{8 , 4 0 4}$ & $\mathbf{1 , 8 7 2}$ \\
\hline
\end{tabular}

Sumber: UN Comtrade (diolah), 2021

Sedangkan di Indonesia, produksi rempah HS 0908 ini belum dilakukan secara intensif. Masih banyak produsen yang menanam rempah HS 0908 dengan pemeliharaan seadanya. Selain itu, masih ada produsen yang mengandalkan hasil produksi dari tanaman yang telah tua dan kurang produktif.
Daya Saing berdasarkan Tingkat Spesialisasi Ekspor Rempah HS 0908 Indonesia di Pasar Internasional

Daya saing rempah HS 0908 Indonesia dapat dilihat dari tingkat spesialisasi perdagangannya. Tingkat spesialisasi perdagangan rempah HS 0908 Indonesia diukur dengan Comparative Export Performance (CEP). Jika Indonesia memiliki nilai CEP lebih besar dari satu maka ekspor rempah HS 0908 yang dilakukan oleh Negara 
Indonesia dikatakan telah terspesialisasi di pasar internasional sehingga dapat dikatakan berdaya saing. Ekspor rempah HS 0908 Indonesia dapat terspesialisasi jika Indonesia menghasilkan dan mengekspor rempah HS 0908 dalam jumlah yang banyak dan dapat memberikan keuntungan bagi Negara Indonesia.

\section{Comparative Export Performance (CEP) Indonesia}

Berdasarkan hasil perhitungan CEP, ekspor rempah HS 0908 Indonesia dikatakan telah terspesialisasi sehingga memiliki daya saing di pasar internasional. Hal tersebut dilihat dari nilai CEP yang selalu bernilai positif lebih dari satu dengan nilai CEP rata-rata sebesar 3,028. Namun, apabila dilihat pada gambar 10, nilai CEP rempah HS 0908 Indonesia pada umumnya mengalami penurunan dari tahun 2004 ke tahun 2018.

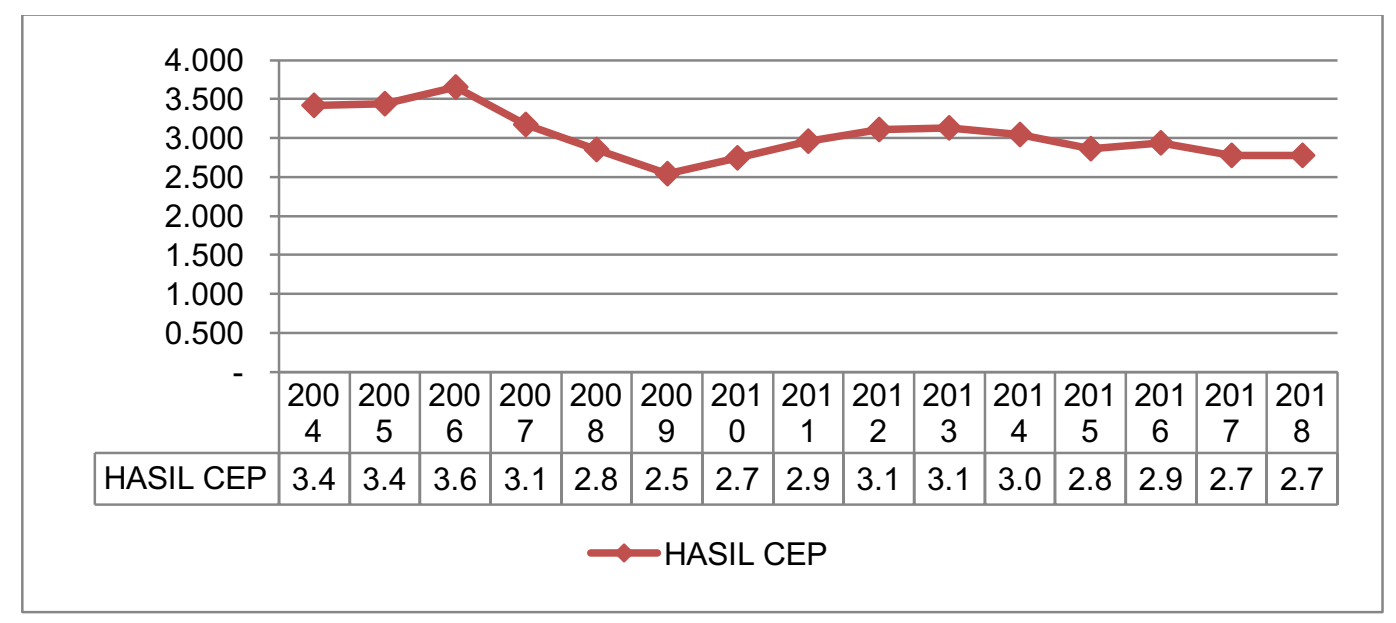

Gambar 10. Nilai CEP Komoditas Pala, Lawang, dan Kapulaga Indonesia

Tahun 2004-2018

Sumber: UN Comtrade (diolah), 2021.

Pada tahun 2004, nilai CEP rempah HS 0908 Indonesia sebesar 3,422 dan tahun 2018 menurun menjadi sebesar 3,028. Nilai CEP tertinggi terdapat pada tahun 2006 yakni sebesar 3,656 . Sama halnya dengan keunggulan komparatif pada pembahasan sebelumnya, spesialisasi ekspor rempah HS 0908 juga dipengaruhi oleh keadaan perdagangan rempah HS 0908 di pasar internasional.

Kenaikan nilai CEP tersebut dipengaruhi oleh peningkatan permintaan rempah HS 0908 Indonesia yang menyebabkan peningkatan volume ekspor dan terjadinya penurunan ekspor pada negara-negara pesaing. Sehingga pada tahun 2006, spesialisasi ekspor negara Indonesia meningkat dan mencapai titik tertingginya selama 


\begin{abstract}
periode 2004-2018. Indonesia pun mencapai daya saing tertingginya pada tahun tersebut.

Nilai CEP terendah rempah HS 0908 Indonesia selama periode 20042018 terjadi pada tahun 2009 yakni sebesar 2,544. Hal tersebut terjadi karena nilai ekspor rempah HS 0908 sebagian negara meningkat yang menyebabkan nilai ekspor total di dunia mengalami kenaikan yang cukup tinggi, sehingga meskipun ekspor rempah HS 0908 Indonesia meningkat pada tahun tersebut, nilai CEP Indonesia mengalami penurunan. Daya saing Indonesia pun menurun.
\end{abstract}

Perbandingan CEP Rempah HS 0908 Indonesia, Guatemala, India, dan Netherland

Berdasarkan hasil perhitungan CEP rempah HS 0908 dari keempat negara tersebut, Negara Guatemala, Indonesia, dan India mempunyai nilai CEP rata-rata lebih dari satu. Sedangkan Negara Netherland memiliki nilai CEP rata-rata kurang dari satu. Hal tersebut menunjukkan bahwa rempah HS 0908 Indonesia, Guatemala, dan India sudah terspesialisasi.

Ketiga negara tersebut dapat dikatakan memiliki daya saing di pasar internasional. Sedangkan Netherland belum atau tidak terspesialisasi sehingga tidak mampu bersaing dengan Negara Indonesia, Guatemala, dan India. Berdasarkan hasil perhitungan CEP, Negara Indonesia memang memiliki daya saing yang cukup kuat. Meskipun demikian, Negara Indonesia memiliki daya saing yang lebih rendah apabila dibandingkan dengan Negara Guatemala yang memiliki nilai CEP rata-rata sebesar 6,731 .

Hal tersebut karena harga dan volume ekspor rempah HS 0908 Guatemala yang lebih tinggi dibandingkan Indonesia, sehingga nilai ekspor rempah HS 0908 Guatemala pun dua hingga tiga kali lipat lebih tinggi dari nilai ekspor rempah HS 0908 Indonesia. Selain itu, produktivitas Guatemala lebih baik dibandingkan Indonesia. Hal tersebut dilihat dari luas lahan produksi dan jumlah hasil produksi rempah HS 0908 antara Indonesia dan Guatemala, dimana selama periode 2004-2018 luas lahan rata-rata Indonesia adalah 119.697 Ha dengan jumlah hasil produksi rata-rata sebanyak 25.596 ton, sedangkan Guatemala memiliki lahan produksi ratarata seluas $72.511 \mathrm{Ha}$ dengan hasil produksi rata-rata sebanyak 31.657 ton. 


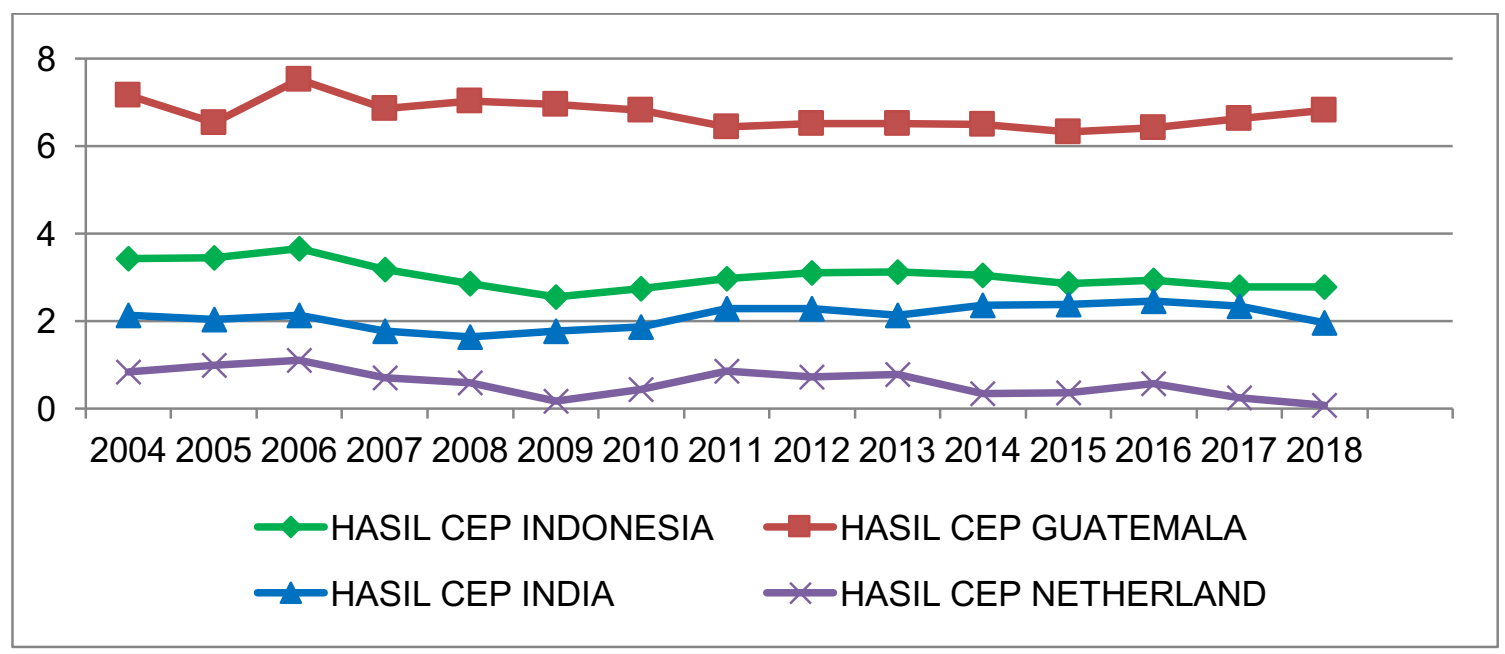

Gambar 11. Perbandingan Nilai CEP Indonesia, Guatemala, India, dan Netherland Sumber: UN Comtrade (diolah), 2021.

Disisi lain, Negara India menjadi negara dengan nilai CEP tertinggi ketiga setelah Negara Guatemala dan Indonesia. Nilai rata-rata CEP India tidak berbeda jauh dari Indonesia yaitu sebesar 2,099. Yang menyebabkan Indonesia unggul dari India selama periode 2004-2018 adalah volume ekspor, dimana volume ekspor rata-rata India pada periode tersebut hanyalah sepertiga dari volume ekspor Indonesia. Permintaan domestik rempah HS 0908 yang lebih tinggi di India ini menjadi salah satu penyebab volume ekspor rempah HS 0908 India lebih rendah dari Indonesia.

Apabila dilihat dari harga ekspor, India lebih unggul dibandingkan Indonesia, sehingga apabila India meningkatkan volume ekspornya, maka nilai CEP India akan meningkat dan menggeser posisi Indonesia. Daya saing India pun akan lebih tinggi dibanding
Indonesia. Netherland menjadi negara dengan nilai CEP terendah dibandingkan Guatemala, Indonesia, dan India. Nilai CEP rata-rata Netherland sebesar 0,583, yang menunjukkan bahwa ekspor rempah HS 0908 di Netherland belum atau tidak terspesialisasi, sehingga dapat dikatakan bahwa rempah HS 0908 Netherland tidak mampu bersaing dengan Negara Guatemala, Indonesia, dan India apabila dilihat dari spesialisasi ekspornya.

Tingkat spesialisasi yang rendah ini berkaitan dengan keadaan Netherland, dimana Netherland bukan merupakan eksportir rempah HS 0908 yang memproduksi rempah tersebut secara mandiri melainkan hasil dari impor yang dilakukan. Sebagian produk digunakan untuk memenuhi kebutuhan domestik, dan sisanya diekspor ke negara lain terutama ke negara-negara di Uni Eropa setelah memberikan perlakuan tambahan 
untuk memperoleh nilai tambah dari rempah HS 0908 tersebut.

\section{KESIMPULAN}

Berdasarkan hasil penelitian dan pembahasan dapat ditarik kesimpulan bahwa rempah HS 0908 Indonesia memiliki daya saing yang cukup tinggi namun cenderung menurun pada periode tahun 2004 ke tahun 2018. Jika dibandingkan dengan negara pesaing, Indonesia berada pada posisi kedua setelah Guatemala, kemudian disusul oleh India dan Netherland. Hal tersebut didasarkan pada:

1. Posisi perdagangan, Indonesia memiliki kecenderungan sebagai eksportir yang berada pada tahap kedewasaan dengan nilai rata-rata ISP Indonesia 0,983. Indonesia berada di posisi kedua setelah Guatemala yang memiliki nilai ISP rata-rata 0,997, lalu disusul oleh India dan Netherland dengan nilai ISP rata-rata masing-masing 0,229 dan $-0,026$.

2. Keunggulan komparatif, Indonesia memiliki keunggulan komparatif tertinggi kedua dengan nilai RCA rata-rata 21,597. Posisi pertama diduduki oleh Guatemala dengan nilai RCA rata-rata 885,830 . Posisi ketiga dan keempat diduduki oleh India dan Netherland dengan nilai RCA rata-rata 8,404 dan 1,872 .
3. Spesialisasi Ekspor, ekspor rempah HS 0908 Indonesia sudah terspesialisasi dengan nilai CEP ratarata 3,028 . Indonesia menduduki posisi kedua setelah Guatemala yang memiliki nilai CEP rata-rata 6,731, kemudian disusul oleh India dan Netherland dengan nilai CEP ratarata 2,009 dan 0,583 .

\section{DAFTAR PUSTAKA}

Food and Agriculture Organization of the United Nations. Crops: Area Hervested and Production Quantity: http://www.fao.org/faostat/en/\#dat a/QC.

Hamdani. 2012. Ekspor-Impor Tingkat Dasar. Bushindo. Jakarta.

Hieronymus Budi Santoso. Ir. ( 1989). Kapulaga. Penerbit Kanisius. Yogyakarta.

Kaynes Maynard J. 1936. The General Theory of Employment, Interest and Money. Palgrace Macmillian. Inggris.

Kementrian Pertanian. 2019. Launching Ekspor Pala Ke Belanda. https://ditjenbun.pertanian.go.id/la unching-ekspor-pala-ke-belanda/

Kementrian Pertanian. 2020. Pandemi, Kapulaga Sumut Tetap Melesat. https://karantina.pertanian.go.id/p ers-1078-pandemi-kapulagasumut-tetap - melesat.html.

Nurdjannah, Nanan. 2007. Teknologi Pengolahan Pala. Badan Penelitian Dan Pengembangan Pertanian.

Tambunan, T. 2004. Globalisasi dan Perdagangan Internasional. PT. Pustaka LP3S. Jakarta. 


\section{Jurnal Agristan}

Vol. 3 No. 2 - November 2021

Halaman. 84-110

Tjitrosoepomo, G. 2005. Taksonomi

Tumbuhan Obat-obatan. UGM

Press. Yogyakarta.

United Nations of Comodity Trade

Database. Get Data: Export, Import:

https://comtrade.un.org/data/.

Utomo, Johan. Dan Suherman, Verdi. 2003. Pembuatan Oleoresin Biji Pala (Myristica fragrans Houtt). Lembaga Penelitian Universitas Katolik Parahyangan. Bandung. 